\title{
Generating the New Dimensions of Social Sustainability into Sustainable Urban Development Policy
}

\author{
Lydia Aulia Kumara ${ }^{1}$ \\ Dyah Mutiarin ${ }^{2}$
}

\begin{abstract}
This paper contributes to the debates on how policy makers face the dilemma on sustainable urban development policies, by addressing social sustainability dimensions. Therefore, it aims to generate out the new dimensions of social sustainability into policy for sustainable urban development. The comprehension gives an insight that favor multi-disciplinary themes, in which it may support national political agenda, particularly in the realms of urban development. Hereby, the research methodology is mapping review; which is held by classifying a new model of social sustainability dimensions. This alternative was proposed to undertake more pressing urgencies in sustainable urban development. Moreover, the study is expected to overcome the ambiguous and complicated elements or key features in determining social sustainability. In general, an implication for urban society is that the new model of social sustainability can be directed to better improve the urban societal development, based on the state of well-being and humane principals.
\end{abstract}

\section{Keywords:}

social sustainability; sustainable urban development; dimensions; well-being

\section{Introduction}

The quandaries frequently experienced by the policy makers, in determining the fundamentals of guidance related to sustainable urban development, as a contemporary issue in public policy outlines the background of this research. For many years, the implementation of this sustainable development in public realm, has drawn an equally muddling conception along with its origin of theoretical frameworks. In the 20th century, the idea of sustainable development established historically due to the societal concern on ecological matters. There was a massive social movement to grow awareness on environmental crisis, since the rapid stream of urbanization occurred unforeseen. This notion of development is no longer debatable, due to the societal requirement on achieving quality of life (QOL). Originally, the conception of sustainability in development was a process to maintain good living condition, by considering the fulfillment of basic needs, while minimizing resources and inputs; with an expectation to produce the state of zero-waste or harmless environment (Keiner, 2005; Du Pisani, 2006; Cahyawati, Djunaedi, \& Kristiadi, 2017). As a respond, the first official legislation of sustainable development was stated on Brundtland Report, supported by World Commission on Environment

\footnotetext{
1 Department of Public Policy and Management, Universitas Gadjah Mada. Email: lydiakumara97@gmail.com

2 Master of Government Affairs and Administration, Universitas Muhammadiyah Yogyakarta. Email: dyahmutiarin@umy.ac.id
} 
and Development (WCED). WCED (1987) argued that sustainable development is development that meets the needs of the present, without compromising the ability of the future generations to meet their own needs (p. 43).

Referring to WCED, sustainable development is purposively understood as a process to ensure the availability of resources demanded by society, without the attempt to undermine the needs of future generations in achieving the fulfillment of resources. Due to the vast urbanization, and statistically growing population, the human activities in fulfilling resources are nevermore affected by solely the environmental aspect. Subsequently, the comprehension of the environmental issues causing the challenges in development became irrelevant. Many scholars had realized there is a necessity to acknowledge development process and outcome beyond ecological matter, including economy and social forces (Du Pisani 2006; Kang 2012). Hence, Koglin (2009) argued the theory of sustainable development became a study of multiple disciplines (pp. 8 -14). This phenomenon led to a further analysis on the relation between sustainable development and urban areas. Since the study of the development had assisted various improvements in the urban and regional planning, it is currently recognized that sustainability as a means towards development mainly, cannot be separated with the study of contemporary urban areas and urban life.

Furthermore, according to Abdullahi and Pradhan (2017) the notion of sustainable urban development was incorporated to grasp the study of relationship between sustainable development and urban planning (pp. 18-19). Sustainable urban development focuses on how the process of being sustainable is established by using less resource or minimum input; meanwhile, at the same time producing less waste or minimum output. By means, being sustainable in urban life means there should be an attempt to reduce the utilization of resources, ensuring the improvement of social equity, and its livability at once. Therefore, a city that has successfully accomplished this pattern of sustainability, frequently applied the most aspects of sustainable urban development. Comparatively, sustainable urban development is specifically classified into three correlated aspects, including: (1) environmental sustainability, (2) economical sustainability, and (3) social sustainability (Du Pisani 2006; Abdullahi \& Pradhan 2017; Cahyawati et al. 2017). First of all, the environmental sustainability is a former aspect of sustainable urban development. This concept provides resolution on crises affecting environmental deterioration. It tends to prioritize concerns on living being, pollution, waste reduction and efficient utilization of natural resources. Second, the economical sustainability was originally established to improve the production of public finance, and to provide employment needs. This economical aspect of the sustainable urban development, generally aims at the economic growth as its foundation (Basiago 1998; Lin \& Yang, 2006, p. 365; Bhattacharya, Oppenheim, \& Stern 2015; Abdullahi \& Pradhan 2017). And third, the existence of social sustainability, as this research will further stress in several chapters below. According to Chiu (2003) social sustainability refers to the maintenance and improvement of well-being in current and future generations (pp. 221 - 239). Thus, a city can be recognized as socially sustainable only when there is a creation of harmonious living environment, reduction of social inequality, cleavages, and an increase in peoples' quality of lives (Enyedi, 2004, pp. 8 - 14).

In brief, a debate on social function in sustainability is vague, as one aspect of sustainable urban development is still controverted; although, this concept has been valued as foremost since it consistently mediates the dimensions purposed by 
environmental and economical sustainability. Sketching from the previous academic literature, this research explores the gap on how generating new dimensions of social sustainability into policy, can fundamentally provide guidance for sustainable urban development. The purpose of this research is to answer the research question: "How the new dimensions of social sustainability can be generated into policy for sustainable urban development?" Particularly, it aims to generate and map out the new dimensions of social sustainability into policy for sustainable urban development. The further illustration gives an insight of new social sustainability dimensions. that favor multiple discipline themes, in which it may support public policy and national political agenda; particularly to pursue a sustained urban development. Lastly, the paper has four parts. First, it reviews the previous relevant academic literatures on sustainable urban development and social sustainability. Second, the research methodology and data collection analysis are discussed. Third, the results are analyzed. And fourth, the conclusion is stated while being followed with the further research attempt.

\section{Literature Review}

\section{Scholars' Key Features Of Social Sustainability}

This section reviews the previous academic and policy literature on social sustainability aspects from various influential scholars in urban planning, sustainable development, urban design, capabilities theory, and economist. Hereby, the analysis on social aspects of sustainability can be proven to have received greater attention in the previous academic literature. However, there are still some ambiguities around what social sustainability actually is, which covers the scope of social sustainability, and to what extent are its limitations, under the terms of sustainable urban development (Littig \& Grießler, 2005; Landorf, 2011). As seen in table 1 , the researcher tries to gather mainly eleven sub-categorization of social sustainability key features, elements, or dimensions in which are equivalent to the discussion of urban development.

Table 1.

Scholars' Key Features on Social Sustainability

\begin{tabular}{cll}
\hline No. & \multicolumn{1}{c}{ Scholars } & Social Sustainability Dimensions \\
\hline 1. & Sustainable & Equity \\
Development & Empowerment \\
Theory & Accessibility \\
Agenda 21 by & Participation \\
Kahn (as cited in & Sharing \\
Basiago 1998) & Cultural identity \\
& & Institutional stability \\
2. Key Issues in & Urban Poverty \\
Maintaining & Migration and Minorities \\
Social & Housing and Urban Renewal \\
Sustainability & Spatial Segregation \\
& \\
(Enyedi 2004) & \\
2007) & Preservation of local characteristics \\
& Ability to fulfill psychological needs \\
& Townscape design \\
& Accessibility \\
& Provision of social infrastructure \\
& Availability of job opportunities
\end{tabular}

Social sustainability seeks to preserve the environment through economic growth and alleviation of poverty. It is not necessarily for a sustained society to degrade environment while compromising on economic growth, in order to achieve poverty alleviation.

Enyedi's argument in social sustainability was to capture public issues, that could happen if there is an unstable sustainability situation viewed from a social perspective. Based on these problems, the government could have a clear guidance on maintaining social sustainability.

Social sustainability can be implemented once there is an urban design consideration to empirically determine critical factors in order to enhance the sustained local urban renewal projects. 


\section{connection from page 191}

4. (Abdullahi and Public service

Pradhan 2017) Security and safety

Population growth

Housing affordability

Accessibility

5. Economic Growth Investment

Theory

Rostow (as cited

in Landorf 2011)

6. Capabilities

Theory

Sen 1985;

Nussbaum (as

cited in Landorf

2011)

7. Sustainable

Livelihoods

Theory

Chambers and

Consumption

Social trends

Normal life expectancy

Bodily health

Bodily integrity

Sense, imagination, and thought

Emotional development

Practical reasoning and critical

reflection

Affiliation with human beings

Concern for other life forms

Ability to play

Control over one's environment

Capability

Equity

Intergenerational sustainability

Conway (as cited

in Landorf 2011)

8. Bramley and Equity

Power (as cited in Social networks

Landorf 2011) Community participation

Pride and identity

Community stability

Security

9. (Landorf 2011) Social equity

Social coherence

Needs satisfaction

10. Sachs (as cited in Equity

Colantonio 2009) Democracy

Human rights

Social homogeneity

Equitable income distribution

Employment

Equitable access to resources and social services

11. Oman and

Education

Spangenberg

(as cited in

Colantonio 2009)

Skills

Experience

Consumption

Income

Employment

Participation
Social sustainability covered the indicators of community safety, social equity, and a generally acceptable level of quality of life to increase life satisfaction for the current and future generations.

Social sustainability is used as a concept to seek a new model, which will address both the original (production and poverty) and future problems of development (environmental resources and inequity).

Social sustainability is having the ability to achieve personal valuation as a human being, in order to accomplish the quality of life. This can be done by establishing freedom, participation, informational focus, intergenerational justice, and also the livelihood of a good human being.

Social sustainability can be defined by viewing through the ability of human to gain and maintain adequate and decent livelihood, both negatively and/or positively. The negative dimension is being reactive, coping with stress and shocks, meanwhile, the positive dimension is being proactive, enhancing and exercising capabilities, creating change, and assuring continuity.

Social sustainability is any action conducted, which is mainly associated with a wider impact on social organization and communities.

The importance of basic needs and equity to achieve social sustainability is being considered. Both concepts are necessary for the physical and psychological survival of individuals.

Social sustainability can only be applied if it rests on basic values of equity and democracy.

Social sustainability comprises every citizen's right to actively participate in his or her society, as an essential element. Oman \& Spangenberg's study on social sustainability emphasis on the importance of social cohesion, action against social exclusion, and participation.

Source: Research results 


\section{Methods}

The methodology focuses on, to analyze the dimensions of the social sustainability assigned in this paper is mapping review, or systematic map. This type of literature review aims to map out essential discoveries, and identify gaps found within previous literature. Additionally, the complexity of search on literature is determined by time or scope constraints, while the result may be graphical or tabular. According to Grant and Booth (2009) mapping review generally should include the characteristics of quantity or quality of literature (e.g., study design or key features) and the comprehension of a broader knowledge, rather than the traditional literature review (pp. 97 - 98). Therefore, the use of systematic map is valuable in offering policy makers, practitioners, and researchers; an explicit and transparent means of identifying narrower policy.

Under those circumstances, the study to fabricate dimensions of social sustainability through a systematic map is expected to collect required information from existing literature found under certain limitations, distinguish the key features gathered into several classifications, and fill in the necessary research gaps discovered from the analysis of different literature. The results are formed as both graphical and tabular figures, in order to illustrate a more thorough analysis of the dimensions required through social sustainability. Lastly, the establishment of mapping review, under the topic of social sustainability, is presumed to suggests policy roadmap or guidelines for policy makers and other expertise in solving problems related to sustainable urban development.

As mentioned before (Petersen et al.,2008) the essential stages of mapping review are: (1) defining the research scope, (2) conducting the search of relevant literature, (3) screening the collection of literature (inclusion and exclusion criteria), (4) classifying the research scheme, and (5) generating data extraction or research outcomes (p. 2). The scope of this research is strictly limited within the terms 'social sustainability' and 'urban development'. The previous literature was collected using various keywords, such as: 'social sustainability', 'social urban project', 'social elements of sustainability', 'social urban renewal', and 'urban sustainability'. Equally important, the searches were constrained to literature in English. As the collection of literature had been screened; therefore, the inclusion criteria are classified by scholars who had proposed theories, key features, indicators, elements, categories, or bullet points referring to the pursuance, driving force, or outcomes coming from the concept of social sustainability merely under the field of sustainable urban development. Meanwhile, the exclusion criteria are specified by the unnecessary influence of environmental or economical aspects of sustainability. This is due to the frequent ambiguous differentiation between these aspects of sustainability. In addition, literature related to social sustainability under the scope of merely sustainable development and not sustainable urban development were also excluded (Kembhavi et al., 2011, pp. 610 - 611).

In summation, the dimensions generated from each scholars' key features of social sustainability are acknowledged to employ different categorizations and fundamental of interpretations. Hence, it is necessary to gather the entire categorizations affecting the pursuance of social sustainability into policy for sustainable urban development by broadly extracting its dimensions. Similarly, to answer the above research question and objective, there is an opportunity to enhance new dimensions through a systematic map, in order to accomplish the fulfillment of research gaps discovered from the previous academic literature.

\section{Results}

The New Dimensions Of Social Sustainability

The purpose of this section is to categorize a new and more broadened view of social 
Figure 1.

The New Dimensions of Social Sustainability

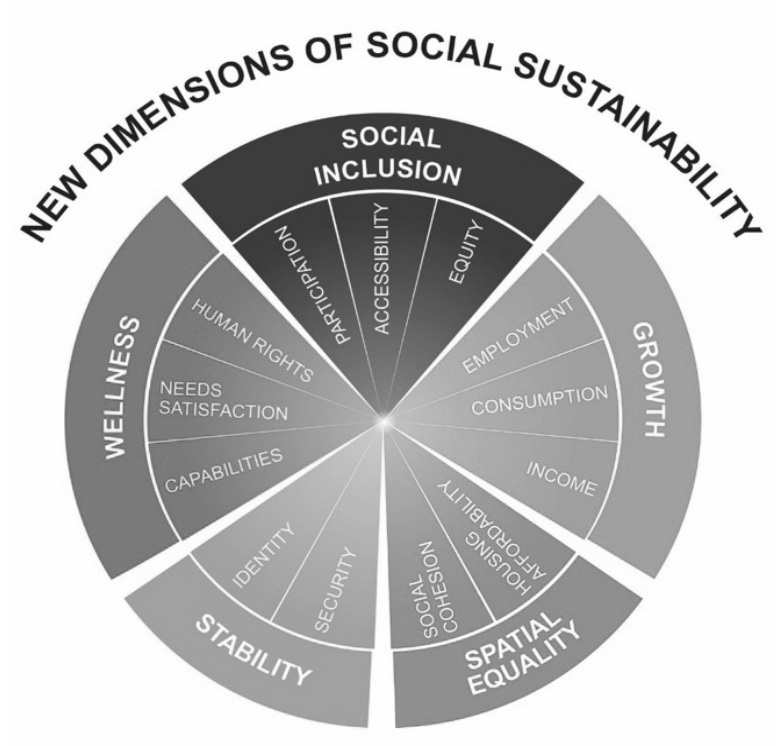

Source: Research results

sustainability in its specific policy realm for sustainable urban development, within the wider thematic debate of sustainable development. As seen in figure 1, there are at least five prominent dimensions in this new model, successfully generated under the scope of urban development, namely; social inclusion, growth, spatial equality, stability, and wellness. Moreover, the further analysis starts by explaining each dimension's definition, and brief contribution towards social sustainability; while also having to determine the importance of sub-elements out of a dimension in representing their integrated and synergetic positions between each other. Since the research focuses on how the social sustainability dimensions would primarily bestow upon policy for sustainable urban development, the discussion on these five new dimensions are also interpreted in governmental and political actions. In brief, this is expected to be a guide to the public policy dilemma in sustainable urban development, as well as answering the earlier research question.

\section{Social Inclusion}

Participation, accessibility, and equity altogether form the concept of social inclusion as one of the first new dimension of social sustainability. Hereby, these foremost subelements can be explained, as follows:

\section{a) Participation}

According to WCED (1987) participation can be determined through the notion of how society must have a political system in place that enables effective public participation in decision making; at the same time, society must have such social systems, which provide solutions for tensions caused by inharmonious development (p. 43). By being socially sustained, participation plays the role of giving a proactive contribution to the society. Engagement of specific activities help to pursue and ease resolution over a public issue regarding the topic of sustainable urban development. Furthermore, public participation also facilitates the promotion of societal specialization and division of roles. The role of specialization is crucial, simply because there is an interdependency and complementary process within the society associated with every daily routine. Without this scheme, the achievement of the welfare state and advanced development would never be successful.

\section{b) Accessibility}

Accessibility generally refers to how 'easily' people can obtain the service that they need (Pitarch-Garrido, 2018). The notion of being socially and publicly accessible mainly relates to spatial and geographical matters. Public service and amenities, henceforth, are considered to be adequate once they are easily accessible by people living nearby. Moreover, accessibility can also be defined by the capability of people to aspire, live, work, enjoy leisure and cultural activities without 
accessing far distance (Chan \& Lee 2007, p. 246). According to Talen and Anselin (as cited in Pitarch-Garrido, 2018), accessibility is a tool used to discover whether or not equity has been achieved. In the sense of social sustainability, the relationship between being equitable and accessible simply cannot be distinguished. Briefly, a socially sustained area can both be regarded as equitable and accessible, once it ensures the whole coverage of basic needs.

\section{c) Equity}

Essentially, equity directs to the fulfillment of public service and facilities in order to accomplish welfare and quality of life. PitarchGarrido (2015) argued equity is a notion of fair (not always equal) distribution of wealth. However, equity often refers to being fair or just, thus, it represents justice. This notion mostly being explained through the terms 'social justice' or 'spatial equity' (Pitarch-Garrido, 2015). By being socially fair and spatially equitable; equity explains how public service and amenities clearly should be accessible to all citizens, without having to represent rivalries and excludability. Meanwhile, the notion of spatial equity elaborates how infrastructure and space are the most essential basic needs; therefore, they should be used fairly. Thus, referring to Harvey (as cited in Pitarch-Garrido, 2015), spatial equity or justice must pursue the following aims, such as: responding to the needs of people in each territory, assigning resources to maximize spatial multiplier effects, and providing extra resources to help overcome the problems occasioned by physical and social environment.

Based on those reference, Farrington and Farrington (2005) argued social inclusion is reviewed to illustrate the participation of people in society, and how to be the converse of social exclusion (pp. 4 -8). According to Philo (as cited in Farrington \& Farrington, 2005, p. 6), social exclusion is a situation where certain members of society are, or become, separated from much that comprises the normal 'round' of living and working in that society. The process of being inclusive in all level of society would only happen if people could possibly embrace the spirit of participation, while also having the power to adequately utilize infrastructures and public amenities in an accessible and equitable way.

In the same way, the pursuance of social sustainability through social inclusion can be implemented by a further government attention on people's common disposition, while addressing the importance of them receiving and experiencing the same matters, as all members of the society would. To begin with, the existence of informal and illegal settlements can accommodate up to eighty percent of the urban populations. Without even realizing, these people actually contribute to the urban economy. However, seeing from another perspective, their basic urban services and amenities are often deprived, creating a notion of social exclusion and inequalities. According to Egypt's experience on building an inclusive city, promoting participatory action mainly overcome the fear of vast urban discrepancy. There are at least five tools proposed, such as: empowering local community; encompassing the promotion of small, responsive, and tangible local initiatives; the use of GIS (Geographical Information System)-based tools to enhance interactive visual measure; promoting "participatory local action planning" approach; and, recognizing the needs of sufficient budget as well as monitoring (US Federal Ministry for Economic Cooperation and Development 2018).

Moreover, to create a socially inclusive city, it is also inevitable to address the integration of towns' diverse functions, to prevent chaotic urban sprawl, and to implement programs in reducing social segregation (Ministry for Regional Development of the Czech Republic 2018). This action requires strong commitments through national sectorial policies included in the socially inclusive urban policy, defined norms 
and standards, universal design approach planning, allocation of necessary resources, and a broad-based partnership of stakeholders, that involves and engages all community members (Ministry for Regional Development of the Czech Republic 2018; UN Department of Economic and Social Affairs 2018).

\section{Growth}

The second new dimension of social sustainability focuses on growth. Whereas, employment, consumption, and income are interconnected between each other to determine the concept of growth itself, which is very much pivotal to economic growth. Below, the sub-elements can be elaborated, such as:

\section{a) Employment}

Employment is a state where people gets assigned to a workforce, as a result of their certain productive working age. Even when the availability of the employment is relevant when compared to the establishment from economical perspective, the social aspect of sustainability is still regarded as one of its main focus. This does not only relate to how people should adequately provide for the job opportunities in order to fulfill their needs of resources, but also on how these working spaces can actually accommodate the social interaction between people (Omann \& Spangenberg, 2002; Chan \& Lee, 2007). According to Stiglitz (as cited in Chan \& Lee, 2007), the divorce rates, suicide rates, and incidence of alcoholism would have emerged more if unemployment rate was high. Additionally, poverty, social exclusion, and psychological problems would have the tendency to reduce when employment rate increases (Omann \& Spangenberg, 2002, p. 3).

For instance, the operationalization of a business company would not be the same if there is no efficient and effective working performance represented by people who works inside. This is not mainly affected by individual achievement in every tasks given, but simply because there is the existence of team works and cooperation. As there is the cycle of employment, economic activities would eventually keep progressing. Shortly, the social networks, flow of information and communication, and the expectation to achieve welfare are all evidence of social contributions inside the fluctuation of employment.

\section{b) Consumption}

Campbell([1995]2005) argued consumption is best believed to define the selection, purchase, use maintenance, repair and disposal of any product or service. Often, the consumption issue is attributed to environmental crises (pp. 95 - 124). However, the behavioral change of engaging a sustainable consumption is much more important than focusing to prevent environmental deterioration. Sustainable consumption can be defined as the activity of consuming resources without compromising the resources needed by future generations. Society needs to envision consumption as a social activity, which requires the active engagement of consumers in order to better enhance their quality of life. The social aspects refer more to the dynamics and social shaping involvement (Briceno \& Stagl, 2006, pp. 1541 - 1544).

\section{c) Income}

The issue on income inequality has negative effects on society that would leave subsequent generations worse off (Meyer \& Kirby, 2014). Since income is prominently related to the daily basis of sustainability, from the social perspective, income inequality may contribute to the state of being politically and socially unstable. A massive movement of union trade, take for example, can only happen if the government decided to establish an unjust policy over income distribution.

Above all, growth, in the sense of economic growth, is a driving force for job creation. Therefore, the levels of growth evidently relate to employment issue (Spangenberg, 2004). The 
availability of employment may lead to the provision of income, and later on consuming goods with the money being earned. Although, economic growth increases the average income; however, it does not automatically reduce the distributional inequalities (Spangenberg, 2004). Therefore, a socially sustained region should represent growth, since it is highly required for a long-term sustainability effect in overcoming inequalities. Hereby, the term of growth can never be equated with economic growth even when this notion drives more urgencies in reality. The existence of growth in social sustainability employs on how society portrays the importance of social interaction, communication, and social networks as the basis of economic growth. In addition, it is also important due to the interrelated circumstances given by the state of employment, adequate income stability, and the enactment of sustainable consumption. Without these kinds of integration and interconnection of people, a sustained welfare state would never be accomplished.

Viewing the perspective of growth in social sustainability can visibly be represented through the continuous cycle of social and economic growth within society to maintain and enhance urban development towards a socially sustained community. Howarth (2012) argued how the economic activities might have an impact on human well-being, by stating that the consumption of material goods and services may satisfy people's preferences, and contributes to their happiness, while higher levels of consumption should, all else equal, contribute positively to social welfare (pp. $36-39)$.

On the other hand, social sustainability has to be central in the discourse on inclusive growth, because not only does continuous growth depends on the continued availability of resources for conducting productivity (Eco-Business, 2018), but focusing on the availability of job opportunities, provision of fair income and adequate resource of sustainable consumption can also help achieve equitable results. Under those circumstances, the government may look up on how Singapore with their unique set of land and resource constraints, dependence on trade and imports, and challenges how to balance the needs of a rapidly growing population with economic growth, become a prime example of how to factor sustainability into policy and urban planning, which can help a city accomplish the status of 'globally competitive city' and 'just city' at the same time (Eco-Business, 2018). Briefly, this city scheme mostly represents how different behavior and mindset of the society portrayed social interaction, communication, and social networks; as the basis of economic growth.

\section{Spatial Equality}

The notion of spatial equality as one new dimension of social sustainability determines the relationship between pursuing social cohesion and housing affordability. To fully understand these sub-elements, here, the definitions can be broadened, as such:

\section{a) Social Cohesion}

Referring to Emile Durkheim, the social cohesion was originally seen as a phenomenon on how social stability could be maintained despite the massive economic changes in the late nineteenth and early twentieth century, specifically in specialization and division of labor (Hulse \& Stone, 2006; Hulse \& Stone, 2007; Hulse \& Stone, 2014). Social cohesion, in terms of social sustainability, defines the sense of solidarity, belonging to the society, bond, or interdependency that commonly generate out of shared values and commitment used to achieve collective goals and satisfaction of citizenship (Council of Europe, 2008; Beumer, 2010). The aim of social cohesion in the society, is to differentiate between the term empowerment, which is an attempt of renewing, rebuilding, or redeveloping unsustainability in communities 
(Hulse \& Stone, 2014). It is not a phase of engagement, but rather a collective movement of being engaged by socially nature force.

However, current social cohesion can be achieved through organic solidarity. Organic solidarity relates to interdependence, shared loyalties, and essential sense of solidarity. Therefore, social cohesion is a 'bottom up' phenomenon. It is sustained through the consistency and development of 'social fabric' or 'social glue' that holds the communities and societies together despite specialized, roles, economic inequality, and differences in social status. Social cohesion dimensions are: (1) reducing 'fault lines' in society, (2) strengthening of social connections and commitment to social groups, (3) and emphasizing shared values, common purpose, and shared identity under social connectedness (Hulse \& Stone, 2006; Hulse \& Stone, 2014).

Social cohesion context is divided into two spheres, which are macro and micro level. The macro context of social cohesion refers to the social fluctuation inside cooperation, market, or governments, while the micro context lowered down to family or households level. Additionally, 'social capital' and 'social exclusion' both specify the occurrence of social cohesion. Social capital is determined as the basis of solidarity sense in which it may escalate along with the position gained in each community or group (Bourdieu as cited in Portes, 1998). Meanwhile, Peace (2001) argued social exclusion or 'social marginalization' can be narrowly defined to explain income poverty phenomenon or broadly defined as income inequality, deprivation or lack of employment (pp. 17-18). Thus, it addresses more on economical processes. In a spatial perspective, social cohesion can be seen through the existence of family or households, neighborhoods, regions, and state.

\section{b) Housing Affordability}

Housing affordability can be defined as the capacity of individuals or households to meet housing costs out of available income, while being able to fulfill another basic need (Arthurson \& Jacobs 2003). In the sense of social sustainability, the affordability of housing is mostly affected by the level of income, societal class or status, the tendency of spatial segregation, and the prevalence of migrants or minorities. According to Newman (2002) the provision of housing in social sustainability generally complies several objectives, such as: ensuring a 'roof overhead' for the housing disadvantage, and ensuring the locational appropriateness of housing (pp. 1-6).

Housing demand, thus, is not merely an economical issue, but also represents the social valuation of housing availability. Additionally, poverty may directly specify whether individuals or households are able to afford housing. In the case of China, housing affordability is one prominent aspect of viewing an independent life. Therefore, the creation of family and marriage often would adjust on their compliance of housing situation (Wang, Han, \& Lim, 2013). In short, housing affordability mainly affects a socially sustained society, because it frequently relates to the situation of housing market, household formation, the demographic changes, and household size structure (Copus \& Crabtree, 1996; Singh et al., 2012; Wang et al., 2013).

In implementing spatial equality, social sustainability covers two major issues particularly in housing affordability and social cohesion. As mentioned earlier, the issue on housing affordability can be discerned from Beijing's experience of its tendency on losing city's attraction, due to the gradually increasing house price, making the condition of housing affordability worse, which would cause unsustainable demographics and population growth (Wang et al., 2013). This situation could be avoided by assessing strategic spatial planning and a strong commitment between the major stakeholders, namely, the government, as a city designer and planner, private sector, and 
society, allowing them to contribute during the planning process (Albrechts, 2004; Martinez \& Fernanda, 2015). Subsequently, there are also new ways of using spatial planning to integrate government (or public sector functions), by focusing on decentralized solutions and integrating the functions of the public sector with a spatial or territorial dimension, as part of their sectorial strategies (Martinez \& Fernanda, 2015).

On the other hand, social cohesion mainly embraces the principles of social capital and against social exclusion. Thus, the overall state of problems surrounding social cohesion are concluded to entirely leads to the case of informal sector. Nowadays, mostly in the developing countries, government focus on informal sector is rather a pressing issue to be undertaken. To overcome the capriciousness of informal sector in the urban area, there should be land regularization and management. This can be done by recognizing the sector's positive contribution, implementing socially regularized land management at the grassroots level, adjust the bottom-up planning approach, and creating a notion of publicprivate partnerships (Martinez \& Fernanda, 2015).

To sum up, according to Kim (as cited in Spence, Annez, \& Buckley, 2009), the basis of spatial equality can be achieved through several policy lessons, among others: understanding the trends of regional industrial economy (e.g. the concentration and dispersion where markets and industrial activities specifically take place); learning the patterns of spatial mobility since they are likely to change over time; understanding the stream of globalization and foreign trade; studying the impact of geographical proximity, as a result of transportation and communication infrastructures; and also understanding the significant role of political institutions. Thereupon, by being spatially equal, society is expected to represents both constant and intact connection to achieve the fulfillment of spatial needs, including infrastructure and mostly housing. Roberts (2003) argued a spatially equal sphere would prefer to emphasis on the development of mechanisms in order to encourage fair belonging and justice being attached to such places (pp. 228-244). Housing availability is a crucial issue underlying social sustainability, since it refers to the aspect of covering human basic needs, namely, the provision of housing, food, and clothing. Social coherence, thus, is seen as a means to accomplish the affordability of spatial needs. Hence, the inclusion of social capital and social exclusion within social cohesion represents the appropriateness of social and economic processes in competing towards housing market situation.

\section{Stability}

In the case of social sustainability, the state of social and community stability is required as a key to achieve sustainable growth. The sense of having identity and being secured at the same time, therefore, eases the struggle to achieve an entity of stabilization. Hereby, both identity and security as the sub-elements for stability's dimension can be elaborated, as follows:

\section{a) Identity}

The social identity concept mainly refers to a sense of belonging or attachment to specific significant surroundings. This process allows people to differentiate themselves from another people based on certain categorizations and labels. The level of selected social identity depends on the situation of interaction, in which the social identification occurs. This process constitutes what may have known elsewhere 'urban social identity' (Valera \& Guàrdia, 2002).

On the other hand, the concept of CityIdentity-Sustainability (CIS) Network assumes that sustainability is not possible without a well- 
established social fabric, that allows people to recognize themselves as a community sharing features. Following psychosocial theories, this identity may be constructed throughout the 'identification model'. This model attributes a person to certain characteristics and values of a group. The 'traditional model', conversely, focused on social cohesion processes. In conclusion, the urban quality of a place might help in the construction of identity (Pol, 2002).

\section{b) Security}

Kwan (2008) argued the foundation of security in social sustainability is valued mainly through the expansion of consumption, enhancement of social security system, and correction of income inequality (p. 3). One of the social sustainability output is security, in which it has been incorporated in peace and sustainable stability (Bervar \& Bertoncelj, 2016, pp. 243 - 244). The quintessence of security through social sustainability reflects through the state of being protected, individually or in the community, so that the pursuance of resources and quality of life is entirely achieved.

As mentioned before, in conclusion, the elements of identity and security altogether are determined to support the necessary aspects of social and community stability. Social stability refers to the valuation of democracy and accountable political system within international norms (Kwan, 2008); meanwhile, community stability can be defined as the situation where residents get to access services, facilities, and dwellings freely and democratically (Wilson \& Taub, 2007). Additionally, there is also a reference claiming the importance of relative stability within the community (Dempsey et al., 2011). By all means, social and community stability can both be differentiated through its personal normative functionality. In social stability, a socially sustained area is the one in which it represents good governance throughout accountability principles and public values, being well-implemented in public institutions. This is the condition when citizens expect the government to have done their morally appropriate task. In community stability, a socially sustained area is the one in which it represents the personal accessibility of basic fulfillment in human needs.

The dimension of being socially stable in a community relies on the representation of social identification, sense of belonging, and the perseverance of being secured. Stability would keep people on the ground; so that they subsequently do the existing and further social activities, in order to support the development mechanism of the urban development. By means, the government needs to attend the pride or sense of place attachment and community stability (Eizenberg \& Jabareen, 2017, p. 68). This can be done by distinguishing place identification. The social identification of specific place was measured by ascertaining from residents, the name of their neighborhood, its territorial extent, their functional use of the neighborhood, and its psychosocial properties (Uzzell, Pol, \& Badenas, 2002). The empathetic impact represents the stability and sustainability of the urban area, since there is a tendency to own and maintain the continuation of such places to grow.

\section{Wellness}

Lastly, the fifth new dimension of social sustainability is stated through wellness. This dimension is consisted of human rights, needs satisfaction, and capabilities as the supporting sub-elements. Below, these sub-elements can be clarified, as such:

\section{a) Human Rights}

Resolution 1819 of General Assembly on the Organization of American States (as cited in UN Association in Canada 2018) asserts: "that the effective enjoyment of all human rights, including the right to education, the rights of assembly and freedom of expression, as well as full enjoyment of economic, social, and cultural rights, could foster 
better environmental protection, by creating conditions conducive to modify behavioral patterns that lead to environmental degradation, reduction of the environmental impact of poverty, and patterns of unsustainable development....". Additionally, Moser (as cited in Takhar, 2015) pointed out that the rights-based approach examines socioeconomic development through a human rights lens. This approach continuously promotes the eradication of marginalization and exclusion, since it is well written as human rights' standpoint of social sustainability. Based on this reference, human rights address issues on how needs fulfillment including education, skills, experience, democracy, gender and sexuality rights, and many other prominent basis of human development are the important elements on achieving socially sustained community.

\section{b) Needs Satisfaction}

To achieve a certain degree of wellness, individuals need a minimum requirement of physical and private consumption, such as: adequate food, shelter, and clothing, as well as certain household equipment and furniture (Hoadley, 1981). Similarly, Kasser (2009) argued that it is also genuinely helpful to attend, based on which people's psychological needs for safety or security, competence, relatedness, and autonomy are satisfied (pp. 176 - 177). Both physical and psychological needs are equally important; reckon, it is nearly impossible for people to live without having each one or even both of them at once. The feeling of satisfaction as a result of needs fulfillment is a final output of having both of the needs being accomplished, directing to the achievement of social sustainability.

\section{c) Capabilities}

According to the capability approach, both Sen \& Nussbaum argue that being socially sustainable means having the ability to achieve personal valuation as human being, in order to accomplish the quality of life (Sen,
1985; Nussbaum, 2000; Voget-Kleschin, 2013). First of all, social sustainability according to Sen is viewed from the orientation of freedom and participation. The pursuance of wellness, therefore, regards freedom and participation as the ethical grounds of socially sustained community. This is mainly to achieve the appraisal of humanity as a whole. Additionally, Sen argues that informational focus in providing societal judgment, whether it is justified or unjustified represents the act of sustainability (Mutlak \& Schwarze, 2010; Ballet et al., 2011; Rauschmayer \& Lessmann, 2013). Secondly, Nussbaum stated that social sustainability can be defined by determining intergenerational justice and conceptualizing optimal resources to live as a good human being (Mutlak \& Schwarze, 2010; Voget-Kleschin, 2013). Referring to Thompson (2010) a society could generate the idea of intergenerational justice, merely when each generation does its fair share to satisfy their needs, to avoid serious harm, and also to have the opportunity of enjoying valuable matters (p. 6). Equally important, the trivial substance of human contribution towards a bigger community scale refers to Nussbaum's fundamental on living as a good human being.

Corbin and Pangrazi (2001) argued wellness can be defined as a multidimensional state of being, describing the existence of positive health as exemplified by the quality of life and a sense of well-being ( $p$. 3). Comparatively, wellness encompasses six elements, namely: physical, emotional, intellectual, spiritual, occupational, and social (City of Fort Collins, 2016, pp. 13 -15). These elements are interrelated between each other, therefore, they are difficult to be distinguished in terms of wellness interpretation. They illustrate how the achievement of wellness is not solely about individuals, but more of internal community interaction and relationships within (City of Fort Collins 2016, pp. 13 -15). To proceed the state of wellness, there should 
be a compliance of human rights, needs satisfaction, and capabilities, as shown below in the discussion. In terms of social sustainability, wellness is expected to guide several patterns of alternatives, such as: increasing overall levels of physical health, increasing access to healthy food, and supporting programs on good mental or behavioral health (City of Fort Collins, 2016, pp. 13 -15).

The state of wellness in social sustainability can be implemented through the achievement of basic human needs. Most of the times, this means the act to pursue a condition of physically and mentally contained as human. In addition, it leads to satisfaction, which is possibly established after acknowledging the result of self-actualization. This can be accomplished through social innovation. Social innovation directs an alternative view of urban development on the satisfaction of human needs and empowerment (e.g. social economy) within community governance. This approach integrates alternative discourses and strategies for re-socializing and redefining identification of urban life (Moulaert et al., 2007). Referring to Moulaert et al. (as cited in Moulaert et al., 2007), active networking of agents and resources across various spatial scales and institutional settings with a strong focus on improving the quality of life is prominent in assessing social innovation in area-based communities. Moreover, Moulaert and Nussbaumer (as cited in Moulaert et al., 2007) argued social innovation can be implemented in the field of urban development, by involving forms of horizontal collaboration in business organization and strengthening the role of arts as well as culture as vehicles to improve communication within communities.

Furthermore, Conway (as cited in Takhar, 2015) argues that the lack of legal acceptance over human rights issues, even until today, seems adequate to encourage the government into putting considerable attention towards this particular dynamic; since there is no guarantee it would be respected by elites or enforced by the state. Subsequently, the City of Fort Collins (2016) created a range of policy recommendations, such as: raising awareness towards active and healthy lifestyle, improving access to mental or behavioral health services and healthy food, preserving and providing responsible access to nature, engaging citizens in education and change behavior towards sustainable living practices, improving safety and accessibility of all modes of travel, and lastly improving the community involvement, education, and regional partnerships.

\section{Conclusion}

Finally, this research has both generate and map out the comprehension on new dimensions of social sustainability, which consist of, namely, the model of new dimensions on social sustainability and an analysis of policy viewed from social sustainability's perspective that is expected to contribute on a broader concept of sustainable urban development.

By fostering a new interpretation from previous academic literature, it is found that the endorsement of social inclusion, growth, spatial equality, stability, and wellness are necessary for a vast and attributed representation of social sustainability dimensions. Altogether, these new dimensions of social sustainability are in an interlocking relationship positions, therefore, should only be implemented in an integrated functioning way. Even though it might have been understood that the dimension of social inclusion is the foremost among all, the dimensions are prominently applicable towards the policy for sustainable urban development. Since, they specifically touch upon the most quintessential matters in social sustainability, which then may work towards the embodiment of urban development. Hereby, the government is valued to address such issues on mainly wellbeing state and humane principal, due to the requirements of increasing urban urgencies. Creating an ambience of community, therefore, 
reappeared as a grassroots' instrument of implementing urban development policies, as well as managing convenient governmental practices and why if truth be told matters for urban societal development.

Furthermore, future research should analyze how the implementation of new dimensions on social sustainability in governmental practice manages to achieve a successful result, as well as conducting a sustained study on new dimensions of social sustainability capability in facing and overcoming contemporary situations.

\section{References}

Abdullahi, S., \& Pradhan, B. (2017). Sustainable Urban Development. Springer International Publishing, 17-34. doi: 10.1007/978-3-31954217-1_2

Albrechts, L. (2004). Strategic (spatial) planning reexamined. Environment and Planning B: Planning and Design, 31(1), 743-758. doi: 10.1068/b3065

Arthurson, K., \& Jacobs, K. (2003). Social exclusion and housing. Retrieved form https://www.ahuri.edu.au/research/finalreports/51.

Ballet, J., Bazin, D., Dubois, J-L., \& Mahieu, F-R. (2011). A note on sustainability economics and the capability approach. Ecological Economics, 70(11), 1831-1834. doi: 10.1016/j.ecolecon.2011.05.009

Basiago, A. D. (1998). Economic, social, and environmental sustainability in development theory and urban planning practice. The Environmentalist, 19(2), 145161. doi: 10.1023/A:1006697118620

Bervar, M., \& Bertoncelj, A. (2016). The five pillars of sustainability: Economic, social, environmental, cultural, and security aspects. Proceedings of the Management International Conference (pp. 243-244). Pula, Croatia.

Beumer, C. (2010). Social cohesion in a sustainable urban neighbourhood.
Proceedings of the SUN Action 2 - SUN Platform and SUN Action 6 (pp. 1-10). The Netherlands and Belgium.

Bhattacharya, A., Oppenheim, J., \& Stern, N. (2015). Driving sustainable development through better infrastructure: Key elements of a transformation program. Proceedings of the Global Economy and Development (pp. 1-34). Addis Ababa, Ethiopia.

Briceno, T., \& Stagl, S. (2006). The role of social processes for sustainable consumption. Journal of Cleaner Production, 14(17), 15411551. doi: 10.1016/j.jclepro.2006.01.027

Cahyawati, E., Djunaedi, A., \& Kristiadi, D. (2017). Symbiocity approach as a conceptual framework for sustainable urban development: Case study of Palu City and Probolinggo City (Master's Thesis). Magister on Urban Planning, Universitas Gadjah Mada, Yogyakarta, Indonesia.

Campbell, C. (2005). The sociology of consumption. In D. Miller (Ed.), Acknowledging Consumption (pp. 95-124). London and New York: Routledge.

Chan, E.W., \& Lee, G.K.L. (2007). Critical factors for improving social sustainability of urban renewal projects. Social Indicators Research, 85(2), 243-256. doi: 10.1007/ s11205-007-9089-3

Chiu, R.L.H. (2003). Social sustainability, sustainable development and housing development: The experience of Hong Kong. In R. Forrest \& J. Lee (Eds.), Housing and Social Change: East-West Perspectives (pp. 221-239). USA: Routledge.

City of Fort Collins. (2016). Fort Collins social sustainability: Strategic plan. City of Fort Collins Social Sustainability, 4-40.

Council of Europe. (2008). Towards an Active, Fair and Socially Cohesive Europe. Report of high level task force on social cohesion, 1-85.

Colantonio, A. (2009). Social sustainability: a review and critique of traditional 
versus emerging themes and assessment methods. LSE Research Online, 865 - 885.

Copus, A., \& Crabtree, J. R. (1996). Indicators of socio-economic sustainability: An application to remote rural Scotland. Journal of Rural Studies, 12, 41-54. doi: 10.1016/0743-0167(95)00050-X

Corbin, C.B., \& Pangrazi, R.P. (2001). Toward a uniform definition of wellness: A commentary. Institute of Education Sciences ERIC, 3(15), 2-10.

Dempsey, N., Bramley, G., Power, S., \& Brown, C. (2011). The social dimension of sustainable development: Defining urban social sustainability. Sustainable Development, 19(5), 289-300. doi: 10.1002/ sd.417

Du Pisani, J.A. (2006). Sustainable development - historical roots of the concept. Environmental Sciences, 3(2), 8396. doi: 10.1080/15693430600688831

Eco-Business. (2018). Sustainability is key to achieving economic growth and social justice. Retrieved from http://www.ecobusiness.com/opinion/sustainability-keyachieving-economic-growth-and-socialjustice/

Eizenberg, E., \& Jabareen, Y. (2017). Social sustainability: A new conceptual framework. Sustainability, 9(1), 68. doi: 10.3390/su9010068

Enyedi, G. (2004). Public participation in socially sustainable urban development. Proceedings of the UNESCO/MOST Program and Centre for Regional Studies (Hungarian Academy of Sciences). Hungary.

Farrington, J., \& Farrington, C. (2005). Rural accessibility, social inclusion and social justice: Towards conceptualisation. Journal of Transport Geography, 13(1), 1-12. doi: 10.1016/j.jtrangeo.2004.10.002

Grant, M.J. \& Booth, A. (2009). A typology of reviews: An analysis of 14 review types and associated methodologies. Health Information \& Libraries Journal, 26(2), 91-
108. doi: 10.1111/j.1471-1842.2009.00848.x. Meyer, C. \& Kirby, J. (2014). Income inequality is a sustainability issue. USA: Harvard Business Publishing.

Hulse, K., \& Stone, W. (2006). Housing, housing assistance and social cohesion. Australian Housing and Urban Research Institute, Swinburne-Monash Research Centre, 9, 1-57. Retrieved from https://www.ahuri. edu.au/_data/assets/pdf_file/0015/2814/ AHURI_Positioning_Paper_No91_ Housing_housing_assistance_and_ social_cohesion.pdf

Hulse, K., \& Stone, W. (2007). Social cohesion, social capital and social exclusion. Policy Studies, 28(2), 109-128. doi: 10.1080/01442870701309049

Hulse, K., \& Stone, W. (2014). Housing and social cohesion: What role for housing policy and assistance?. Research Gate, 1528. https://www.academia.edu/17977771/ Housing_and_Social_Cohesion_ What_Role_for_Housing_Policy_and_ Assistance?auto=download

Hoadley, J.S. (1981). The rise and fall of the basic needs approach. Applied Geography, 1(4), 309-311. doi: 10.1177/001083678101600302

Howarth, R.B. (2012). Sustainability, well-being, and economic growth. Retrieved from https://www.humansandnature.org/ filebin/pdf/minding_nature/Sept-2012_ Sustainability_WellBeing.pdf

Kang, J. (2012). A study on the future sustainability of sejong, south korea's multifunctional administrative city, focusing on implementation of transit oriented development (Master's Thesis). Sustainable Development, Uppsala University, Uppsala, Sweden.

Kasser, T. (2009). Psychological Need Satisfaction, Personal Well-Being, and Ecological Sustainability. Ecopsychology, 1(4), 175-180. doi: 10.1089/eco.2009.0025

Keiner, M. (2005). Re-emphasizing sustainable development: The concept 
of Evolutionability. Environment, Development and Sustainability, 6(4), 379392. doi: $10.1007 / \mathrm{s} 10668-005-5737-4$

Kembhavi, G., Darrah, J., Payne, K., \& Plesuk, D. (2011). Adults with a diagnosis of cerebral palsy: A mapping review of longterm outcomes. Developmental Medicine and Child Neurologyl, 53(7), 610-614. doi: 10.1111/j.1469-8749.2011.03914.x

Koglin, T. (2009). Sustainable development in general and urban context: A literature review. (Bulletin 248/3000; Vol. Bulletin 248/3000). Lund University Faculty of Engineering, Technology and Society, Traffic and Roads, Lund, Sweden.

Kwan, C.H. (2008). Social stability as the key to sustainable growth: Transition to democracy and a system in line with international norms needed. Retrieved from https://www.jcer.or.jp/eng/pdf/ chinasum08.pdf

Landorf, C. (2011). Evaluating social sustainability in historic urban environments. International Journal of Heritage Studies 17(5), 463-477.doi: 10.1080/13527258.2011.563788

Lin, J-J., \& Yang, A-T. (2006). Does the compactcity paradigm foster sustainability? An empirical study in Taiwan. Environment and Planning B: Planning and Design, 33(3), 365. doi: 10.1068/b31174

Littig, B., \& Grießler, E. (2005). Social sustainability: A catchword between political pragmatism and social theory. International Journal of Sustainable Developmen, 8(1-2), 65. doi: 10.1504/ IJSD.2005.007375

Ministry for Regional Development of the Czech Republic. (2018). Principles of Urban Policy. Retrieved from http://www.mmr. cz/getmedia/f333120b-88d5-4bd8-bec9dd58a26f9812/principles_of_urban_ policy.pdf

Martinez, G., \& Fernanda, M. (2015). Social sustainability in the land use planning process of bogotá (Master's Thesis). School of Engineering, Aalto University, Espoo, Finland.

Moulaert, F., Martinelli, F., González, S., \& Swyngedouw, E. (2007). Introduction: social innovation and governance in European cities. European Urban and Regional Studies 14(3), 195-209. doi: 10.1177/0969776407077737

Mutlak, N., \& Schwarze, R. (2010). Elements of a theory of social sustainability: Taking stock of social-science approaches. Retrieved from https://www.researchgate.net/ publication/259465973_Elements_of_a_ theory_of_social_sustainability_Taking_ stock_of_social-_science_approaches

Newman, P. (2002). Sustainability and housing: More than a roof over head. Retrieved from http://citeseerx.ist.psu.edu/viewdoc/dow nload?doi=10.1.1.482.7658\&rep=rep1\&t ype $=$ pdf

Nussbaum, M.C. (2000). Women and human development: The capabilities approach. Cambridge: Cambridge University Press. Omann, I., \& Spangenberg, J.H. (2002). Assessing Social Sustainability: The Social Dimension of Sustainability in a SocioEconomic Scenario. Proceedings of the 7th Biennial Conference of the International Society for Ecological Economics, Sousse, 1-20. Retrieved from http://citeseerx.ist. psu.edu/viewdoc/download;jsessionid= 469EE76DA42C4C827FDE5FF865383D3 6?doi=10.1.1.201.987\&rep=rep1\&type=pdf Peace, R. (2001). Social exclusion: A concept in need of definition. Social Policy Journal of New Zealand, 16, 17-35. Retrieved from https://pdfs.semanticscholar.org/49fb/ fc52499c1bc094a2a0d42e4b0f5b90fab402. pdf

Petersen, K., Feldt, R., Mujtaba, S., \& Mattsson, M. (2008). Systematic mapping studies in software engineering. 12th International Conference on Evaluation and Assessment in Software Engineering (EASE), 1-10. 
Retrieved form http://www.robertfeldt. net/publications/petersen_ease 08 _ sysmap_studies_in_se.pdf

Pitarch-Garrido, M-D. (2015). Social sustainability through accessibility and equity. Local Development Research Institute, Department of Geography, University of Valencia. Retrieved form https://sustainabledevelopment. un.org/content/documents/5918Social $\% 20$ sustainability $\% 20$ through $\% 20$ accessibility\%20and\%20equity.pdf

Pitarch-Garrido, M-D. (2018). Social sustainability in metropolitan areas: Accessibility and equity in the case of the metropolitan area of valencia (Spain). Sustainability, 10(2), 371. https://ideas.repec.org/a/gam/jsusta/ v10y2018i2p371-d129632.html

Pol, E. (2002). The theoretical background of the city-identity-sustainability network. Environment and Behavior, 34(1), 8-25. doi: 10.1177/0013916502034001002

Portes, A. (1998). Social capital: Its origins and applications in modern sociology. Annual Review of Sociology, 24, 1-24. doi: 10.1146/ annurev.soc.24.1.1

Rauschmayer, F., \& Lessmann, O. (2013). The Capability Approach and Sustainability. Journal of Human Development and Capabilities, 14(1), 1-5. doi: 10.1080/19452829.2012.751744

Roberts, P. (2003). Sustainable development and social justice: Spatial priorities and mechanisms for delivery. Sociological Inquiry, 73(2), 228-244. doi: 10.1111/1475$682 X .00054$

Sen, A. (1985). Commodities and Capabilities. Oxford: Elsevier Science Publishers.

Singh, R. K., Murty, H. R., Gupta S. K., \& Dikshit A. K. (2012). An overview of sustainability assessment methodologies. Ecological Indicators, 15, 281-299. doi: 10.1016/j.ecolind.2011.01.007

Spangenberg, J. H. (2004). Reconciling sustainability and growth: criteria, indicators, policies. Sustainable Development, 12(2), 74-86. doi: 10.1002/ sd.229

Spence, M., Annez, P. C., \& Buckley, R. M. (2009). Urbanization and growth. Commission on Growth and Development World Bank, 1-213. Retrieved from http:// hdl.handle.net/10986/2582

Takhar, S. (2015). Sustainability, human rights, and sexuality: Making the right connections. Local Economy: The Journal of the Local Economy Policy Unit, 30(3), 256-264. 10.1177/0269094215580084

Thompson, J. (2010). What is Intergenerational Justice?. Retrieved from http://www. futureleaders.com.au/book_chapters/pdf/ Future_Justice/Janna_Thompson.pdf

UN Associations in Canada. (2018). The human rights approach to sustainable development: environmental rights, public participation, and human security. Retrieved from http:// unac.org/wp-content/uploads/2013/07/ HRandSD-EN-PDF.pdf

UN Department of Economic and Social Affairs. (2018). Good practices of accessible urban development: making urban environments inclusive and fully accessible to all. Retrieved from http://www.un.org/disabilities/ documents/desa/good_practices_ in_accessible_urban_development_ october2016.pdf

US Federal Ministry for Economic Cooperation and Development. (2018). The Inclusive City: Documentation of a joint networking event of the German Federal Ministry for Economic Cooperation and Development (BMZ) and the Cities Alliance at the World Urban Forum 3 - 21 June 2006 in Vancouver. Retrieved from https://www. bmz.de/en/publications/archiv/type_ of_publication/information_flyer/flyer/ KonferenzberichtTheInclusiveCity.pdf

Uzzell, D., Pol, E., \& Badenas, D. (2002). Place identification, social cohesion, and environmental sustainability. 
Environment and Behavior, 34(1), 26-53. doi: 10.1177/0013916502034001003

Valera, S., \& Guàrdia, J. (2002). Urban social identity and sustainability: Barcelona's Olympic Village. Environment and Behavior, 34(1), 54-66. doi: $10.1177 / 0013916502034001004$

Voget-Kleschin, L. (2013). Employing the capability approach in conceptualizing sustainable development. Journal of Human Development and Capabilities, 14(4), 483502. doi: 10.1080/19452829.2013.827635

Wang, Z., Han, J.H., \& Lim, B. (2013). The impacts of housing affordability on social and economic sustainability in Beijing. Australasian Journal of Construction Economics and Building - Conference Series, 12(1), 47-55. doi: 10.5130/ajceb-cs.v1i1.3154

Wilson, W. J. \& Taub, R. P. (2007). There goes the neighborhood: Racial, ethnic, and class tensions in four Chicago neighborhoods and their meaning for America. Michigan Sociological Review, 21, 239-244. doi: 10.1111/j.1468-2427.2010.01022_5.x

World Commission on Environment and Development. (1987). Our Common Future (Brundlandt Report). Oxford: Oxford University Press. 